\title{
Pengaruh Metode Pembelajaran dan Kemampuan Berpikir Kreatif Terhadap Hasil Belajar Sejarah Siswa di SMA Negeri 5 Depok Kelas 11 IPS
}

\author{
Yusuf Budi Prsetya Santosa, Tuti Nuriah, Murni Winarsih, Sarkadi \\ Pendidikan Sejarah Pascasarjana Universitas Negeri Jakarta \\ prasetyabudi29@gmail.com
}

\begin{abstract}
This research has a purpose to determine the extent of the influence fromproblem solving method and the ability to learn think creatively for the outcomes of studyinghistory for students in public high school 5 Depok class of 11 IPS. This research is a quantitative research by using experimental methods, treatment by level $2 x 2$ design. The instrument used tolearn history is a multiple choice test and for the test for ability to think creatively is questionnaire. 1) The results of the methods showed that the learning outcomes from students who take the history learning with instructional solving methods (problem solving) higher than students who follow conventional teaching methods; 2) there are significant interactions between instructional solving method (problem solving) and the creative thinking ability for students learning outcomes of history; 3) the results of studying the history of students who take the learning solving method (problem solving) with creative thinking ability, higher than the historical learning outcomes of students who take conventional teaching methods with high creative thinking abilities; 4) the results of learning the history of students who take the method of problem solving (problem solving) with creative thinking ability is low, lower than the historical learning outcomes of students who take the instructional conventional methods and low creative thinking ability.
\end{abstract}

Keywords: result of historical learning, instructional method, ability to think creatively.

\begin{abstract}
Abstrak:Penelitian ini memiliki maksud untuk untuk mengetahui sejauh mana pengaruh metode pembelajaran pemecahan masalah (problem solving) dan kemampuan berpikir kreatif terhadap hasil belajar sejarah siswa di SMA Negeri 5 Depok kelas 11 IPS. Penelitian ini adalah jenis penelitian kuantitatif dengan menggunakan metode eksperimen desain treatment by level $2 \times 2$.Instrumen yang digunakan untuk hasil belajar sejarah adalah tes pilihan ganda dan untuk kemampuan berpikir kreatif adalah kuisioner. 1) hasil penelitian menunjukan bahwa hasil belajar sejarah siswa yang mengikuti metode pembelajaran pemecahan masalah (problem solving) lebih tinggi dari siswa yang mengikuti metode pembelajaran konvensional; 2) terdapat pengaruh interaksi antara metode pembelajaran pemecahan masalah (problem solving) dan kemampuan berpikir kreatif siswa terhadap hasil belajar sejarah; 3) hasil belajar sejarah siswa yang mengikuti metode pembelajaran pemecahan masalah (problem solving) dengan kemampuan berpikir kreatif tinggi, lebih tinggi dari hasil belajar sejarah siswa yang mengikuti metode pembelajaran konvensional dengan kemampuan berpikir kreatif tinggi; 4) hasil belajar sejarah siswa yang mengikuti metode pemecahan masalah (problem solving) dengan kemampuan berpikir kreatif rendah, lebih rendah dari hasil belajar sejarah siswa yang mengikuti metode pembelajaran konvensioal dengan kemampuan berpikir kreatif rendah.
\end{abstract}

Kata Kunci : hasil belajar sejarah, metode pembelajaran, kemampuan berpikir kreatif 


\section{PENDAHULUAN}

Pembelajaran sejarah diharapkan mampu membentuk siswa menjadi siswa yang memiliki karakter baik, yang sesuai dengan nilai-nilai kebangsaan. Selain itu dengan belajar sejarah diharapkan siswa mampu mengembangkan daya kreatifitasnya, karena sejarah mengajarkan berpikir kreatif. Penelitian ini perlu dilakukan untuk melihat korelasi antara metode pembelajaran dengan hasil belajar sejarah siswa.

Peran seorang guru sangat dibutuhkan, karena guru bukan hanya sebagai pengajar, melainkan juga sebagai fasilitator, pembimbing, motivator, organisator, dan sumber belajar. Sebagai fasilitator dan pendidik, guru harus pandai dan cerdas dalam memilih dan menggunakan metode pembelajaran apa yang akan digunakan dalam proses pembelajaran. Sesuai dengan kedudukan metode pembelajaran itu sendiri, yaitu sebagai alat ekstrinstik, strategi pembelajaran, dan sebagai alat mencapai tujuan. Metode sebagai alat ekstrintik maksudnya ialah bagaimana guru menggunakan metode yang tepat dan bervariasi, serta dapat dijadikan alat motivasi dalam proses pembelajaran.

Penggunaan metode pembelajaran sangat menentukan hasil belajar siswa. Penggunaan metode pembelajaran yang tepat dapat membuat siswa mendapatkan hasil belajar yang tinggi dan dapat mengembangkan potensi yang tersimpan dalam dirinya, sehingga siswa akan termotivasi untuk belajar. Metode pembelajaran yang tepat akan membuat pelajaran sejarah tidak akan dianggap lagi sebagai pelajaran yang membosankan. Siswa akan tertarik apabila yang dipelajarinya menarik, relevan dengan kebutuhannya, dan menambah rasa puas serta percaya diri.Terdapat banyak jenis metode pembelajaran, salah satunya adalah metode pembelajaran pemecahan masalah.

Berdasarkan observasi peneliti di SMAN 5 Depok, ditemukan fakta fakta antara lain seringkali saat proses pembelajaran sejarah sedang berlangsung, siswa justru tidak memperhatikan penjelasan guru. Hal ini terlihat ketika guru memberikan pertanyaan, seringkali siswa tidak mampu menjawab pertanyaan tersebut. Pada saat guru menjelaskan materi di depan kelas, sebagian besar siswa tidak memiliki motivasi untuk belajar.

Kebanyakan para siswa sibuk dengan aktivitasnya masing-masing, seperti mengobrol dengan teman, bermain dengan gawaiyang dimilikinya, mengerjakan tugas pelajaran lain, atau tertidur. Beberapa siswa mencoba mendengarkan, akan tetapi sikap dan mimik wajahnya nampak tidak bersemangat. Sebagian besar siswa enggan untuk bertanya jika menemui kesulitan perihal memahami materi yang dijelaskan oleh guru. Sikap siswa ini bisa terjadi karena berbagai macam faktor, salah satunya ialahpenggunaan metode pembelajaran yang tidak tepat oleh guru. 
Mayoritas Guru Sejarah pada umumnya lebih senang menggunakan metode yang konvensional, seperti ceramah yang cenderung membuat pembelajaran menjadi membosankan, dan monoton.

Bruce Joyce \& Marsha Weil (1986: 2-3) Menjelaskan metode pembelajaran merupakan, "plan or pattern that we can use to design face-to-face teaching in classroom or tutorial settings and to shape instructional materials.Direct procedures that get immediate result to complex strategiest that students can acquire only after patient and skillful instruction.

Thompson (1959:296) mengenai metode pebelajaran pemecahan masalah menjelaskan, "The method is directly applied in essentially the same manner time and time again. There is no need for a new approach, no need for intergrating prior experiences, no rewuirement for discovery, and no delay in finding the appropriate procedure for the correct answer."

Hasil penelitian yang relevan terhadap penelitian ini, ialah penelitian yang dilakukan oleh Sumardiansyah yang berjudul "Pengaruh Metode Pembelajaran dan Kemampuan Berpikir Kreatif Terhadap Hasil Belajar Sejarah". Dari hasil penelitian-penelitian tersebut didapati kesimpulan, bahwa terdapat interaksi antara metode pembelajaran dan kemampuan berpikir kreatif terhadap hasil belajar sejarah.

Penelitian ini dilakukan mengingat masih banyak guru yang belum menerapkan strategi pembelajaran yang tepat untuk meningkatkan hasil belajar sejarah siswa. Metode pembelajaran pemecahan masalah dianggap cukup mumpuni untuk digunakan sebagai metode pembelajaran yang tepat, guna menumbuhkan kemampuan berpikir kreatif.

Penelitian ini bertujuan untuk mencari tahu apakah terdapat perbedaan hasil belajar sejarah dan pengaruh interaksi, antara siswa yang mengikuti metode pembelajaran pemecahan masalah (problem solving) dengan siswa yang mengikuti metode pembelajaran konvensional ceramah. Serta apakah terdapat perbedaan hasil belajar sejarah, antara siswa dengan kemampuan berpikir kreatif tinggi maupun siswa dengan kemampuan berpikir kreatif rendahyang mengikuti metode pembelajaran pemecahan masalah (problem solving) dengan siswa yang mengikuti metode pembelajaran konvensional ceramah atau sebaliknya.

\section{METODE}

Pendekatan yang digunakan dalam penelitian ini ialah pendekatan kuantitatif dengan metode eksperimen dengan desain treatment by level $2 \mathrm{x}$ 2.Metode eksperimen merupakan metode yang digunakan untuk menguji hipotesis menyangkut hubungan sebab akibat. Metode eksperimen digunakan untuk meneliti ada tidaknya pengaruh dengan cara memberikan perlakuan terhadap kelas eksperimen yang hasilnya dibandingkan dengan kelas kontrol. 
Penelitian ini merupakan penelitian kuantitatif yang dilakukan secara prosedural dan sistematis.Prosedur pengumpulan data dalam penelitian ini menggunakan teknik random sampling dalan bentuk kuisioner terbatas.Data yang dikumpulkan dalam penelitian, yaitu hasil belajar sejarah siswa dan skor kemampuan berpikir kreatif siswa. Data dikumpulkan dengan menggunakan instrumen dengan tahap pengembangannya, yaitu instrumen hasil belajar sejarah dan instrumen variabel kemampuan berpikir kreatif.

Instrumen yang digunakan dalam penelitian ini adalah tes hasil belajar dalam bentuk pilihan ganda dengan 5 pilihan jawaban, yaitu A, B, C, $\mathrm{D}$, dan E, dimana dalam pilihan tersebut hanya memiliki satu jawaban yang benar. Butir soal objektif bentuk pilihan ganda terdiri atas pokok soal dan alternatif pilihan jawaban. Instrumen hasil belajar dilakukan uji validitas dengan point biserial dan dikonsultasikan kepada dosen pembimbing. Perhitungan reliabilitas menggunakan rumus Kuder Richardson 20

Populasi target dalam penelitian merupakan siswa SMAN 5 Depok yang berjumlah 1310 dari 31 kelas. Populasi terjangkau dalam penelitian merupakan siswa kelas XI IPS yang berjumlah 189 dari 5 kelas. Sampel dalam penelitian merupakan kelas XI IPS SMAN 5 Depok Jawa Barat yang berjumlah 98 orang dengan rincian kelas XI IPS 149 siswa dan kelas XI IPS 5 49 siswa.

Penelitian ini menggunakan teknik analisis data digunakan analisis Varians (ANAVA) 2 jalur. Sebelum uji tersebut dilakukan terlebih dahulu dilakukan uji persyaratan analisis yaitu uji normalitas dan uji homogenitas data. Uji normalitas menggunakan uji liliefors, sedangkan uji homogenitas menggunakan uji bartlett. Apabila hasil variasi menunjukkan adanya pengaruh utama (main effect) dari variabel bebas terhadap variabel terikat dan terdapat interaksi (interaction effect) antar variabel bebas dalam hubungannya dengan variabel terikat, maka analisis dilanjutkan dengan uji Tukey guna menguji hipotesis penelitian lebih lanjut.

\section{HASIL}

Berdasarkan rencana eksperimen yang disusun dalam penelitian ini, maka terdapat enam kelompok hasil belajar yang akan dideskripsikan.Keenam kelompok tersebut antara lain: 1) hasil belajar sejarah secara keseluruhan siswa yang mengikuti metode pembelajaran pemecahan masalah (problem solving); 2) hasil belajar sejarah siswa secara keseluruhan yang mengikuti metode pembelajaran Konvensional; 3) hasil belajar sejarah siswa dengan kemampuan berpikir kreatif tinggi yang mengikuti metode pembelajaran pemecahan masalah (problem solving); 4) hasil belajar siswa dengan kemampuan berpikir kreatif tinggi yang mengikuti metode pembelajaran Konvensional; 5) hasil belajar sejarah siswa 
dengan kemampuan berpikir kreatif rendah yang mengikuti metode pembelajaran pemecahan masalah (problem solving); 6) hasil belajar sejarah siswa dengan kemampuan berpikir kreatif rendah yang mengikuti metode pembelajaran Konvensional.

Tabel 1.

Rangkuman hasil perhitungan Analisis Varians (ANAVA) dua jalur

\begin{tabular}{|c|c|c|c|c|c|c|c|}
\hline \multirow{2}{*}{ Sumber Variansi } & \multirow{2}{*}{$\mathrm{Db}$} & \multirow{2}{*}{ JK } & \multirow{2}{*}{ RJK } & \multirow{2}{*}{\multicolumn{2}{|c|}{$\mathrm{F}_{\text {hitung }}$}} & \multicolumn{2}{|c|}{$F_{\text {tabel }}$} \\
\hline & & & & & & 0.05 & 0.01 \\
\hline Metode Pembelajaran (A) & 1 & 138.94 & 138.94 & 8.986 & $*$ & 4.04 & 7.19 \\
\hline Berpikir Kreatif (B) & 1 & 152.33 & 152.33 & 9.852 & $*$ & 4.04 & 7.19 \\
\hline Interaksi (A x B) & 1 & 824.02 & 824.02 & 53.295 & $* *$ & 4.04 & 7.19 \\
\hline Dalam & 48 & 742.15 & 15.46 & & & & \\
\hline Total Direduksi (TR) & 51 & 1857.44 & & & & & \\
\hline
\end{tabular}

Penjelasan hasil belajar sejarah siswa yang mengikuti metode pembelajaran pemecahan masalah (problem solving) secara keseluruhan, dimana tanpa ada pembedaan tingkatan berpikir kreatif ialah sebagai berikut. Jumlah sampel 26 siswa dengan rentang skor 23 dimana skor tertinggi 36 dan skor terendah 13. Rentang skor teoritiknya $0-40$. Rerata skornya 24,46, modus 22,32, median 20,50, varians 49,14 dan simpang bakunya 7,01 dibandingkan rentang skor teoritiknya 0 - 40 dengan rerata skor yang diperoleh siswa yaitu 24,46 maka, dapat dikategorikan sedang.

Banyaknya siswa yang mendapatkan skor pada kelas interval 13 - 16 ada 3 siswa (11,5\%), siswa yang mendapatkan skor pada kelas interval 17 20 ada 8 siswa $(30,8 \%)$, siswa yang mendapatkan skor pada kelas interval 21 - 24 ada 2 siswa $(7,7 \%)$, siswa yang mendapatkan skor pada kelas interval 25 - 28 ada 4 siswa $(15,4 \%)$, siswa yang mendapatkan skor pada kelas interval 29 - 32 ada 4 siswa $(15,4 \%)$, dan siswa yang mendapatkan skor pada kelas interval 33 - 36 ada 5 siswa $(19,2 \%)$.

Penilaian terhadap hasil belajar sejarah siswa yang menggunakan metode pembelajaran konvensional tanpa membedakan tingkat kemampuan berpikir kreatif dapat digambarkan sebagai berikut. Jumlah sampelnya 26 siswa dengan rentang skor 19, dimana skor tertinggi 36 dan skor terendah 13. Rentang skor teoritiknya $0-40$, dimana rerata skornya 21,19 , modus 20,94, median 6,50, varians 19,60, dan simpang bakunya 4,43.

Bahwa banyaknya siswa yang mendapatkan skor pada kelas interval 13 - 16 ada 3 siswa (11,5\%), siswa yang mendapatkan skor pada kelas interval 17 - 20 ada 9 siswa (34,6\%), siswa yang mendapatkan skor pada kelas interval 21 - 24 ada 10 siswa (38,5\%), siswa yang mendapatkan skor pada kelas interval 25 - 28 ada 2 siswa $(7,7 \%)$, siswa yang mendapatkan skor 
pada kelas interval 29 - 32 ada 1 siswa (3,8\%), dan siswa yang memperoleh skor pada kelas interval 33 - 36 ada 1 siswa $(3,8 \%)$.

Hasil belajar sejarah siswa yang mengikuti metode pembelajaran pemecahan masalah (problem solving) dengan kemampuan berpikir kreatif tinggi dapat digambarkan sebagai berikut. Jumlah sampel 13 siswa dengan rentang skor 17, dimana skor tertinggi 38 dan skor terendah 19. Rentang skor teoritiknya 0 - 40, dimana rerata skornya 30,15, modus 31,50, median 30,90, varians 20,97, dan simpang bakunya 4,58. Jika dibuat perbandingan, antara rentang skor teoritiknya $0-40$ dengan rerata skornya 30,15 maka dikategorikan cukup tinggi.

Bahwa banyaknya siswa yang mendapatkan skor pada kelas interval 19- 22 ada 1 siswa (7,7\%), siswa yang mendapatkan skor pada kelas interval 23 - 26 ada 1 siswa $(7,7 \%)$, siswa yang mendapatkan skor pada kelas interval 27 - 30 ada 4 siswa $(30,8 \%)$, siswa yang mendapatkan skor pada kelas interval 31 - 34 ada 5 siswa (38,5\%), dan siswa yang mendapatkan skor pada kelas interval 35 - 38 ada 2 siswa (15,4\%).

Data hasil belajar sejarah siswa yang mengikuti metode pembelajaran pemecahan masalah (problemsolving) dengan kemampuan berpikir kretif rendah dapat digambarkan sebagai berikut. Jumlah sampel 13 siswa dengan rentang skor 13, dimana skor tertinggi 27 dan skor terendah 13. Rentang skor teoritiknya $0-40$, yang mana rerata skornya 18,77, modus 17,64 , median 18,25, varians 11, 19, dan simpang bakunya 3,35. Jika dibuat perbandingan antara rentang skor teoritiknya, yaitu 0 - 40 dengan rerata 18,77 maka dapat dikategorikan sedang.

Bahwa banyaknya siswa yang mendapatkan skor pada kelas interval 13 - 15 ada 1 siswa $(7,7 \%)$, siswa yang mendapatkan skor pada kelas interval 16 - 18 ada 6 siswa $(46,2 \%)$, siswa yang mendapatkan skor pada kelas interval 19 - 21 ada 4 siswa (30,8\%), siswa yang mendapatkan skor pada kelas interval 22 - 24 ada 1 siswa $(7,7 \%)$, dan siswa yang mendapatkan skor pada kelas interval $25-27$ ada 1 siswa $(7,7 \%)$.

Hasil belajar sejarah siswa yang mengikuti metode pembelajaran konvensional dengan kemampuan berpikir kreatif tinggi dapat digambarkan sebagai berikut. Jumlah sampel 13 siswa dengan rentang skor 8, dengan skor tertingginya 24 dan skor terendah15. Rentang skor teoritiknya $0-40$, dimana rerata skornya 18,92, modus 18,50, median 20,00, varians 6,74, dan simpang bakunya 2,60. Jika dibuat perbandingan antara rentang skor teoritiknya 0 40 dengan rerata 18,92 maka dapat dikategorikan sedang.

Bahwa banyaknya siswa yang mendapatkan skor pada kelas interval 15 - 16 ada 3 siswa (23,1\%), siswa yang mendapatkan skor pada kelas interval 17 - 18 ada 2 siswa (15,4\%), siswa yang mendapatkan skor pada kelas interval 19 - 20 ada 4 siswa (30,8\%), siswa yang mendapatkan skor 
pada kelas interval 21 - 22 ada 3 siswa (23,1\%), dan siswa yang mendapatkan skor pada kelas interval 23 - 24 ada 1 siswa $(7,7 \%)$.

Hasil belajar sejarah siswa yang mengikuti metode pembelajaran konvensional dengan kemampuan berpikir kreatif rendah dapat digambarkan sebagai berikut. Jumlah sampel 13 siswa dengan rentang skor 17, dimana skor tertinggi 36 dan skor terendah 17. Rentang skor teoritiknya 0 - 40, dimana rerata skornya 23,46, modus 22,21, median 22,83, varians 22,94, dan simpang bakunya 4,79 . Jika dibuat perbandingan antara rentang skor teoritiknya 0 - 40 dengan rerata skornya 23,46, maka dapat dikategorikan sedang.

Bahwa banyaknya siswa yang mendapatkan skor pada kelas interval 17 - 20 ada 3 siswa $(23,1 \%)$, siswa yang mendapatkan skor pada kelas interval 21 - 24 ada 6 siswa (46,2\%), siswa yang mendapatkan skor pada kelas interval 25 - 28 ada 2 siswa $(15,4 \%)$, siswa yang mendapatkan skor pada kelas interval 29 - 32 ada 1 siswa $(7,7 \%)$, dan siswa yang mendapatkan skor pada kelas interval 33 - 36 ada 1 siswa $(7,7 \%)$.

Pengujian hipotesis dapat dilakukan setelah persyaratan untuk pengujian analisis telah terpenuhi, yaitu uji normaliras dan uji homogenitas. Pengujian hipotesis ini dilakukan guna menguji semua efek utama serta efek interaksi terhadap hasil belajar siswa dengan menggunakan analisis varians dua jalur (ANAVA) 2x2.

Dampak utama dalam penelitian ini adalah tentang pengaruh penggunaan metode pembelajaran pemecahan masalah (problem solving) dan kemampuan berpikir kreatif terhadap hasil belajar sejarah siswa SMA 5 Depok kelas 11 IPS. Kemudian dampak interaksinya mengenai adanya pengaruh interaksi antara penggunaan model pembelajaran yang diberikan kepada siswa yang memiliki kemampuan berpikir kreatif rendah.Tahap signifikansi selanjutnya dilakukan dengan uji lanjut menggunakan Uji Tuckey.

Berdasarkan perhitungan ANAVA dua jalur didapat Fhitung untuk metode pembelajaran sebesar 8,986 sedangkan $\mathrm{F}_{\text {tabel }}=4,04$ pada taraf

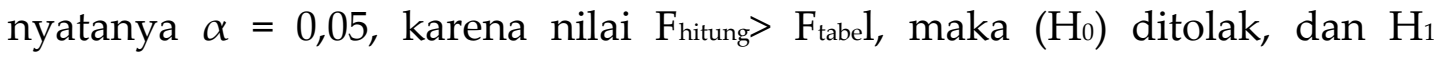
diterima. Artinya terdapat perbedaan hasil belajar sejarah antara siswa yang mengikuti metode pembelajaran pemecahan masalah (problem solving) dengan siswa yang mengikuti metode pembelajaran konvensional.

Pada uji hipotesis kedua terdapat pengaruh interaksi antara penggunaan metode pembelajaran pemecahan masalah (problem solving) dan kemampuan berpikir kreatif terhadap hasil belajar sejarah siswa.

Berdasarkan hasil perhitungan ANAVA dapat dilihat bahwa Fhitung untuk faktor interaksi, yaitu 53,295 lebih besar dari pada $F_{\text {tabel }}$ yaitu 4,04 pada taraf nyata $\alpha=0,05$. Hal ini menunjukan, bahwa terdapat pengaruh interaksi 
antara penggunaan metode pembelajaran dan kemampuan berpikir kreatif siswa terhadap hasil belajar. Dari data tersebut dapat disimpulkan, $\mathrm{H}_{0}$ ditolak dan $\mathrm{H}_{1}$ diterima.

Pada uji hipotesis ketiga hasil belajar sejarah siswa yang mengikuti metode pembelajaran pemecahan masalah (problem solving)dengan kemampuan berpikir kreatif tinggi dari siswa yang mengikuti metode pembelajaran konvensional dengan kemampuan berpikir kreatif tinggi.

Nilai rerata dari hasil belajar sejarah siswa dengan kemampuan berpikir kreatif tinggi yang mengunakan metode pembelajaran pemecahan masalah (problem solving) (A1B1) adalah 30,15, sedangkan nilai rerata hasil belajar sejarah siswa dengan kemampuan berpikir kreatif tinggi yang menggunakan metode pembelajaran konvensional (A2B1) adalah 18,92. Kedua nilai ini diperbandingkan dengan menggunakan Uji Tuckey hasilnya menunjukan, bahwa Qhitung, yaitu 10,30 > Qtabel, yaitu 4,04 pada taraf signifikansinya $\alpha=0,05$. Maka dengan demikian dapat disimpulkan, bahwa $\mathrm{H}_{0}$ ditolak dan $\mathrm{H}_{1}$ diterima. Jadi, terdapat perbedaan hasil belajar sejarah siswa yang memiliki kemampuan berpikir kreatif tinggi, yang menggunakan metode pembelajaran pemecahan masalah (problem solving) dan yang menggunakan metode pembelajaran konvensional.

Pada uji hipotesis keempat hasil belajar sejarah siswa dengan kemampuan berpikir kreatif rendah yang mengikuti metode pembelajaran pemecahan masalah (problem solving) lebih rendah dari siswa yang mengikuti metode pembelajaran konvensional.

Nilai rerata hasil belajar sejarah siswa dengan kemampuan berpikir kreatif rendah yang mengikuti metode pembelajaran pemecahan masalah (problem solving) (A1B2) adalah 18,77, sedangkan nilai rerata hasil belajar sejarah siswa dengan kemampuan berpikir rendah yang menggunakan metode pembelajaran konvensional (A2B2) adalah 23,46. Hasil Uji Tuckey dari kedua nilai tersebut menunjukan, bahwa Qhitung yaitu 4,30 lebih besar daripada Qtabel yaitu 4,04 pada taraf signifikansinya $\alpha=0,05$. Maka dengan demikian dapat disimpulkan, bahwa $\mathrm{H}_{0}$ ditolak dan $\mathrm{H}_{1}$ diterima. Jadi terdapat perbedaan hasil belajar sejarah siswa yang memiliki kemampuan kreatif rendah yang menggunakan metode pembelajaran pemecahan masalah (problem solving), dengan siswa berkemampuan berpikir kreatif rendah yang menggunakan metode pembelajaran konvensional.

Dari hasil analisis data diketahui bahwa penggunaan metode pembelajaran pemecahan masalah (problem solving) memiliki dampak lebih tinggi dalam memaksimalkan hasil belajar sejarah siswa SMA 5 Depok Kelas 11. Siswa mendapatkan hasil belajar sejarah yang lebih baik bila diberikan metode pembelajaran pemecahan masalah (problem solving). 


\section{PEMBAHASAN}

Berdasarkan hasil observasi awal yang sudah dilakukan di SMA Negeri 5 Depok hasilnya ditemukan proses pembelajaran yang cenderung bersifat menghafal, guru hanya membeberkan fakta-fakta tanpa ada proses dialektis yang mendalam. Hal ini berdampak pada tidak responsifnya siswa, yang berakibat pada macetnya daya berpikir kreatif siswa.Akhirnya pelajaran sejarah tidak begitu diperhatikan oleh para siswa.

Pembelajaran sejarah diharapkan mampu membentuk siswa menjadi siswa yang memiliki karakter baik, yang sesuai dengan nilai-nilai kebangsaan.Selain itu dengan belajar sejarah diharapkan siswa mampu mengembangkan daya kreatifitasnya, karena sejarah mengajarkan berpikir kreatif.Penelitian ini perlu dilakukan untuk melihat korelasi antara metode pembelajaran dengan hasil belajar sejarah siswa.

Hasil penelitian diketahui bahwa pada hipotesis pertama Hoditolak dan $\mathrm{H}_{1}$ diterima.Penelitian memperlihatkan bahwa siswa yang mengkuti metode pembelajaran pemecahan masalah (problem solving) lebih tinggi dari siswa yang mengikuti metode pembelajaran konvensional.Hipotesis kedua Hoditolak dan $\mathrm{H}_{1}$ diterima, diketahui bahwa terdapat interaksi antara metode pembelajaran pemecahan masalah (problem solving) dan kemampuan berpikir kreatif.Hipotesis ketiga diketahui bahwa Hoditolak dan Hiditerima, siswa yang mengikuti metode pembelajaran pemecahan masalah (problem solving) dengan kemampuan berpikir kreatif tinggi, lebih tinggi hasil belajar sejarah siswa yang mengikuti metode pembelajaran konvensional.Hipotesis keempat diketahui bahwa $\mathrm{H}_{0}$ ditolak dan $\mathrm{H}_{1}$ diterima, hal ini ditunjukan dengan siswa yang mengikuti metode pembelajaran pemecahan masalah (problem solving) dengan kemampuan berpikir kreatif rendah, lebih rendah hasil belajar sejarah siswa yang mengikuti metode pembelajaran konvensional dengan kemampuan berpikir kreatif rendah.

Hasil uji keempat hipotesis tersebut diperoleh hasil, bahwa keempat hipotesis terbukti karena terdapat interaksi sehingga diperoleh kesimpulan bahwa: 1) hasil penelitian menunjukan bahwa hasil belajar sejarah siswa yang mengikuti metode pembelajaran pemecahan masalah (problem solving) lebih tinggi dari siswa yang mengikuti metode pembelajaran konvensional; 2) terdapat pengaruh interaksi antara metode pembelajaran pemecahan masalah (problem solving) dan kemampuan berpikir kreatif siswa terhadap hasil belajar sejarah; 3) hasil belajar sejarah siswa yang mengikuti metode pembelajaran pemecahan masalah (problem solving) dengan kemampuan berpikir kreatif tinggi, lebih tinggi dari hasil belajar sejarah siswa yang mengikuti metode pembelajaran konvensional dengan kemampuan berpikir kreatif tinggi; 4) hasil belajar sejarah siswa yang mengikuti metode pemecahan masalah (problem solving) dengan kemampuan berpikir kreatif 
rendah, lebih rendah dari hasil belajar sejarah siswa yang mengikuti metode pembelajaran konvensioal dengan kemampuan berpikir kreatif rendah.

Berdasarkan kesimpulan tersebut, maka implikasi penelitian ini antara lain; 1) metode pembelajaran pemecahan masalah (problem solving) dapat menjadi pilihan sebagai salah satu metode alternatif yang dapat memaksimalkan hasil belajar sejarah siswa; 2) guru perlu mempertimbangkan tingkat berpikir kreatif siswa bilamana ingin memaksimalkan hasil belajar sejarah siswa dengan menggunakan metode pembelajaran pemecahan masalah (problem solving); 3) siswa yang memiliki kemampuan berpikir kretif tinggi lebih baik untuk mengikuti metode pembelajaran pemecahan masalah (problem solving) yang mampu mendorong siswa untuk mengembangkan kemampuan berpikir kreatif; 4) siswa yang memiliki kemampuan berpikir kreatif rendah lebih baik untuk mengikuti metode pembelajaran konvensional.

Dari hasil penelitian menunjukan, bahwa hasil belajar sejarah siswa yang telah mengikuti metode penelitian pemecahan masalah (problem solving) lebih tinggi dari hasil belajar sejarah siswa yang mengikuti metode pembelajaran konvensional. Selain itu terdapat pengaruh interaksi antara metode pembelajaran dan kemampuan berpikir kreatif siswa terhadap hasil belajar sejarah siswa.

Terdapat perbedaan hasil belajar sejarah siswa yang mengikuti metode pembelajaran pemecahan masalah (problem solving) dengan kemampuan berpikir kreatif tinggi, lebih tinggi dari hasil belajar sejarah siswa yang mengikuti metode pembelajaran konvensional dengan kemampuan berpikir kreatif tinggi. Ditemukan fakta, bahwa hasil belajar sejarah siwa yang mengikuti metode pembelajaran pemecahan masalah (problem solving) dengan kemampuan berpikir kreatif rendah, lebih rendah dari hasil belajar sejarah siswa yang mengikuti metode pembelajaran konvensional dengan kemampuan berpikir kreatif rendah.

\section{PENUTUP}

Berdasarkan kesimpulan tersebut, maka implikasi penelitian ini antara lain; metode pembelajaran pemecahan masalah dapat menjadi pilihan sebagai salah satu metode alternatif yang dapat memaksimalkan hasil belajar sejarah siswa; guru perlu mempertimbangkan tingkat berpikir kreatif siswa bilamana ingin memaksimalkan hasil belajar sejarah siswa dengan menggunakan metode pembelajaran pemecahan masalah; siswa yang memiliki kemampuan berpikir kretif tinggi lebih baik untuk mengikuti metode pembelajaran pemecahan masalah (problem solving) yang mampu mendorong siswa untuk mengembangkan kemampuan berpikir kreatif; 
siswa yang memiliki kemampuan berpikir kreatif rendah lebih baik untuk mengikuti metode pembelajaran konvensional.

Implikasi penelitian ini antara lain: (1) Metode pembelajaran pemecahan masalah (problem solving) dapat menjadi pilihan sebagai salah satu metode alternatif yang dapat memaksimalkan hasil belajar sejarah siswa. (2) Guru perlu mempertimbangkan tingkat berpikir kreatif siswa bilamana ingin memaksimalkan hasil belajar sejarah siswa dengan menggunakan metode pembelajaran pemecahan masalah (problem solving). (3) Siswa yang memiliki kemampuan berpikir kretif tinggi lebih baik untuk mengikuti metode pembelajaran pemecahan masalah (problem solving) yang mampu mendorong siswa untuk mengembangkan kemampuan berpikir kreatif. (4) Siswa yang memiliki kemampuan berpikir kreatif rendah lebih baik untuk mengikuti metode pembelajaran konvensional.

\section{DAFTAR PUSTAKA}

[1] Joyce, Bruce dan Weil, Marsha.(1986).Models of Teaching.New Jersey: Prentice Hall International. Inc.

[ 2 ] Kusuma, Sumardiansyah Perdana.(2014).Pengaruh Metode Pembelajaran dan Kemampuan Berpikir Kreatif Terhadap Hasil Belajar Sejarah.Jakarta: Jurnal Vol. 3 No 2.

[3] Thompson, George. G.(1959).Educational Psychology.New York: Appleton Century Crofts. 